\title{
Controlled trial of whole body protein synthesis and plasma amino acid concentrations in yearling horses fed graded amounts of lysine
}

* Corresponding author. Tel.: +1 8592577748.

1 Current address: Department of Animal Science, South Dakota State University, Brookings, SD

S.L. Mastellar ${ }^{1}$, R.J. Coleman, K.L. Urschel *

Department of Animal and Food Sciences, University of Kentucky, Lexington, KY 40546, USA 57007, USA. 
Abstract

Lysine has been reported as the first limiting amino acid in typical equine diets. Indicator amino acid oxidation (IAAO) has become the standard method for determining amino acid requirements in other species, but prior to this study has not been used to determine equine requirements. The aim of this study was to evaluate whole body protein synthesis and plasma and muscle amino acid concentrations in response to graded levels of lysine intake in yearling horses. Six Thoroughbred colts $(358 \pm 5 \mathrm{~kg})$ were fed each of six treatment lysine intakes ranging from 76 to $136 \mathrm{mg} / \mathrm{kg}$ body weight/day. Blood samples were taken before and $90 \mathrm{~min}$ after the morning concentrate meal. Gluteal muscle biopsies were taken $100 \mathrm{~min}$ after the morning concentrate meal. The next day, whole body phenylalanine kinetics were determined using a $2 \mathrm{~h}$ primed, constant infusion of $\left[{ }^{13} \mathrm{C}\right]$ sodium bicarbonate followed by a $6 \mathrm{~h}$ primed, constant infusion of $\left[1-{ }^{13} \mathrm{C}\right]$ phenylalanine. Plasma lysine concentrations increased linearly $(P<0.05)$ at both the 0 and 90 min time points with increasing lysine intakes. Free muscle asparagine, aspartate, arginine, glutamine, lysine, taurine and tryptophan concentrations responded quadratically to lysine intake $(P<0.05)$.

31 Phenylalanine kinetics did not differ between treatment intakes $(P>0.10)$. A broken line analysis of lysine intake and phenylalanine oxidation failed to yield a breakpoint from which to determine a lysine requirement. These diets may have been limiting in an amino acid other than lysine, underscoring the lack of data concerning amino acid requirements and bioavailability data in the horse. 


\section{Introduction}

Compared to human beings and pigs, relatively little work has been done to elucidate amino acid requirements for horses. Currently, the NRC (2007) lists only a crude protein requirement and

41 a lysine requirement in the requirement tables and software. Identifying amino acid requirements for various physiological states (NRC, 2012) has helped the pig industry to minimize nitrogenous waste (Panetta et al., 2006) without compromising pig growth (Tuitoek et al., 1997). The environmental impacts of excess nitrogen output from equine operations have been reviewed by Bott et al. (2015). Other consequences of overfeeding protein to horses could be compromised respiratory health from increased ammonia output (Whittaker et al., 2009), disrupted acid-base balance (Graham-Thiers and Kronfeld, 2005b) and decreased bone mineralization from increased calcium excretion through urine (Glade et al., 1985). Determining amino acid requirements in horses will allow diet formulation to more closely match equine needs. al., 2005; Tome and Bos, 2007). It has been found to be limiting in some diets for growing horses (Breuer and Golden, 1971; Potter and Huchton, 1975; Ott et al., 1981; Fisher et al., 1989; Graham et al., 1994). However, these studies in horses generally were not designed to measure specific lysine requirements and they did not use isonitrogenous treatments, but rather used treatments with different protein sources and/or did not include many levels of lysine intake. The NRC (2007) applied broken line analysis to seven studies that reported diet composition, intake and nitrogen retention to estimate a lysine requirement at $4.3 \%$ of the crude protein requirement (NRC, 2007). This lysine requirement as a percentage of crude protein is in line with other species (Ball et al., 2007), but has not been confirmed experimentally in horses. The current NRC (2007) recommendation for lysine for yearling horses is $113 \mathrm{mg} / \mathrm{kg}$ body weight $(\mathrm{BW}) /$ day. 
Isotopic methods have been used in other species to determine amino acid requirements

6

(Bertolo et al., 2005; Kurpad and Thomas, 2011). These methods are based on the concept that amino acids that cannot be used for protein synthesis are oxidized to $\mathrm{CO}_{2}$. The production of $\mathrm{CO}_{2}$ from amino acid metabolism can be determined from an infusion of a $1-{ }^{13} \mathrm{C}$-labeled amino acid and measuring ${ }^{13} \mathrm{CO}_{2}$ expelled in the breath. Using an isotopic essential amino acid other than the amino acid being tested as an indicator of amino acid metabolism is known as the indicator amino acid oxidation (IAAO) method (Brunton et al., 1998; Elango et al., 2008). As the dietary intake of a test amino acid, such as lysine, increases, less of the indicator or $1-{ }^{13} \mathrm{C}$-labeled amino acid is oxidized until a plateau is reached. The intersection of this decline and plateau of the rate of ${ }^{13} \mathrm{CO}_{2}$ release from the indicator amino acid defines the requirement of the test amino acid. The isotope infusion technique necessary to determine requirements via the IAAO method has been adapted to horses and validated (Urschel et al., 2012). In addition to calculating amino acid requirements, the isotopic data can also yield estimates of rates of whole body protein synthesis and breakdown (Waterlow et al., 1978).

(1)

This study investigated the responses of whole body protein synthesis in addition to plasma and tissue amino acid concentrations in yearling horses receiving graded levels of lysine. The lysine levels included levels both above and below the current NRC (2007) recommendations. We hypothesized that a breakpoint would be seen in our phenylalanine kinetics data denoting a lysine requirement for yearling horses.

\section{Materials and methods}

Animals, housing, and feeding

All procedures used in this study were approved by the University of Kentucky Institutional Animal Care and Use Committee (IACUC 2008-0385). Six yearling Thoroughbred colts were obtained from University of Kentucky Maine Chance Farm for use in this study in May 2011. The 
IAAO method has successfully been used to determine amino acid requirements in other species using five to six subjects (Bertolo et al., 2005; Elango et al., 2007; Levesque et al., 2011). A sample size calculation confirmed that six horses were appropriate (PS Power and Sample Size Calculations Program, version 2.1.3.1).

The adaptation diet consisted of hay cubes and a half and half mix of the concentrates used in the treatment diets. The 2 week adaptation period to diet and housing was followed by six 1 week treatment periods. Yearlings were housed in individual dry lot pens and all sampling procedures were conducted in individual sawdust bedded stalls $(3.7 \mathrm{~m}$ x $3.7 \mathrm{~m})$ except for muscle biopsies, which were collected from horses in stocks. A livestock scale (TI-500, Transcell Technology) was used to obtain daily body weights.

Diets were designed to meet or exceed the 2007 Nutrient Requirements of Horses recommendation, with the exception of lysine (NRC, 2007). Two isonitrogenous and isocaloric versions of the same concentrate pellets were formulated for this study (Tables 1 and 2). The only differences between the two concentrates were that one contained free lysine, and the other an isonitrogenous amount of free glycine and a small amount of rolled oats to account for the difference in weight of the added glycine versus lysine. By mixing the two concentrates at different ratios and feeding timothy hay cubes at the same rate for all treatments, six treatment diets were created with lysine intakes of 76, 90, 104, 118, 127 and $136 \mathrm{mg} / \mathrm{kg} \mathrm{BW/day.} \mathrm{Three} \mathrm{of} \mathrm{the} \mathrm{lysine}$ intakes were above the estimated lysine requirement of $113 \mathrm{mg} / \mathrm{kg} \mathrm{BW} /$ day and three of the intakes were below. Glycine was selected because it is a dispensable amino acid and not metabolically related to lysine. The concentrate was provided at $1.11 \%$ of BW/day with timothy hay cubes at $1.37 \%$ of BW/day (Table 1). Timothy was used as the forage component of the diets because of its relatively low lysine content (Woodward et al., 2011). Concentrate and hay cubes were fed twice daily (0700 and $1500 \mathrm{~h}$ ) with water and salt available at all times. Feed was collected throughout the 
115 study and four samples of each feedstuff were sent to Dairy One Cooperative for proximate analysis

116 at the conclusion of the study. Weekly feed samples were analyzed for amino acid content as

117 described below.

\section{Study design and procedures}

Horses were studied in a group of two and a group of four with similar birth dates within each group to facilitate sample collection. Splitting the horses into groups allowed all the horses to be studied at similar ages and further minimize variation. Diets were fed in a random order within the groups, with the stipulation that no two horses were on the same treatment diet at the same time. Treatment assignments were made after horses were selected for the study using a random number generator, such that each treatment was represented in each period and each horse only received each treatment a single time,. Researchers were not blinded to the treatments to provide multiple checks to ensure that each horse received the correct diet during each period. Each horse received each diet as in a 6 x 6 Latin square design.

Following the initial adaptation, treatment diets were fed for a period of 7 days each. This length of adaptation was chosen because less than 2 days of adaptation has been found to be sufficient for human beings (Elango et al., 2009) and pigs (Moehn et al., 2004), but the effect of adaptation time on IAAO analyses has not yet been ascertained in horses. On day 6 of treatment, blood samples $(10 \mathrm{~mL})$ were collected by venipuncture immediately before and $90 \mathrm{~min}$ after the morning concentrate meal into an evacuated glass tube containing a heparin to measure plasma glucose, insulin, urea nitrogen and amino acid concentrations. Horses were then sedated with 100 $\mathrm{mg} / \mathrm{mL}$ xylazine (AnaSed Lloyd Laboratories) administered IV at a dose of $0.5 \mathrm{mg} / \mathrm{kg} \mathrm{BW}$. Muscle biopsies ( $\sim 500 \mathrm{mg})$ were taken after sedation took effect ( 100 min post-feeding) from the gluteus medius at a depth of $\sim 6 \mathrm{~cm}$ with a Bergstrom needle (Lindholm and Piehl, 1974). The muscle was immediately frozen in liquid nitrogen. While the horses were still sedated, both jugular veins were 
141 catheterized, one side for isotope infusion and the other for blood sampling (Urschel et al., 2012) in 142 preparation for the following day's procedures.

On day 7 of treatment, whole body phenylalanine kinetics were measured as described previously (Mastellar et al., 2016b), with the exception that the infusion of $\left[1-{ }^{13} \mathrm{C}\right]$ phenylalanine continued for $6 \mathrm{~h}$ instead of only $4 \mathrm{~h}$. Upon completion of the isotope infusion procedures, catheters were removed and the yearlings were allocated to their next treatment, beginning with their afternoon concentrate meal for that day. Samples were collected during the months of May, June and July of 2011. Yearlings were returned to University of Kentucky Maine Chance Farm research herd at the end of the study.

Analysis of samples

Blood samples - Heparinized vacutainers (Vacutainer; Becton-Dickinson) were used for blood collection. Samples were inverted and then promptly centrifuged at $1500 \mathrm{~g}$ for $10 \mathrm{~min}$ at $4{ }^{\circ} \mathrm{C}$. Plasma was removed and frozen at $-20^{\circ} \mathrm{C}$ until the time of analysis.

Amino acids - Plasma free, muscle free and total feed amino acid concentrations were measured using reverse phase high performance liquid chromatography (HPLC; 3.9 x $300 \mathrm{~mm}$ PICO-TAG reverse phase column; Waters) of phenylisothiocyanate derivatives, as previously described (Urschel et al., 2011). Muscle samples were freeze dried (Miller-Graber et al., 1990) and homogenized in $6 \mu \mathrm{L} / \mu \mathrm{g}$ of $0.4 \mathrm{mM}$ nor-leucine made in $0.1 \mathrm{~N} \mathrm{HCl}$ prior to deproteination. Both muscle homogenates and plasma samples were deproteinated by centrifugation at $14,000 \mathrm{~g}$ for 30 min at $4{ }^{\circ} \mathrm{C}$ using $10 \mathrm{kDa}$ cutoff centrifugation filters (Urschel et al., 2011). Six samples of each

164 feedstuff collected throughout the study were used for amino acid analyses (AOAC, 2005), with each sample analyzed in duplicate. 
to determine plasma glucose concentrations enzymatically. The intra-assay variation was $1.5 \%$ with

169 all samples being run in a single batch. As previously described (Urschel et al., 2007), a

170 colorimetric spectrophotometric assay was used to determine plasma urea nitrogen, with an intraassay variation of $3.5 \%$ and an inter-assay variation of $<10 \%$. A Coat-A-Count RIA kit (Siemens Healthcare Diagnostics), previously validated for use in horses (Reimers et al., 1982), was used to determine plasma insulin concentrations. analyzer (IRIS-2; Wagner Analysen Technik Vetriebs GmbH). Phenylalanine isotopic enrichment, representing the relative concentrations of $\left[1-{ }^{13} \mathrm{C}\right]$ phenylalanine to unlabeled phenylalanine, in plasma samples was measured by Metabolic Solutions using a previously described method (Matthews et al., 1990).

\section{Calculations}

Whole body phenylalanine kinetics - The average enrichment at plateau was determined for blood and breath sample enrichments, where a plateau was defined as at least three points with a 185 slope that was not different from $0(P>0.05)$ using linear regression analyses (GraphPad Prism 4 186 Software). Whole body phenylalanine flux, oxidation, non-oxidative disposal and phenylalanine 187 balance were calculated as previously described (Tanner et al., 2014). Intake was adjusted for 188 estimated prececal digestibilities of 40 and $70 \%$ for forage and concentrate, respectively, based on a 189 review by Martin-Rosset and Tisserand (2004), and a splanchnic extraction of 26.5\% (Mastellar et 190 al., 2016a) to more accurately reflect the absorbed phenylalanine entering general circulation. Non191 oxidative phenylalanine disposal was used as an indicator of whole body protein synthesis. 
192 Conversion of phenylalanine to tyrosine was considered negligible and, if any occurred, the intake 193 of phenylalanine and tyrosine was the same across treatments.

Statistical analysis

Data were analyzed using the MIXED procedure in SAS version 9.1.3 (SAS Institute), unless otherwise noted. Differences were considered to be significant at $P<0.05$. One-way analysis of variance (ANOVA) with treatment as the fixed effect and horse as the random effect, including analysis for linear, quadratic and cubic orthogonal contrasts, was used to evaluate phenylalanine kinetics parameters, pre-feeding and post-feeding plasma glucose, insulin, urea and amino acid concentrations, and muscle amino acid concentrations. Period and group were originally included in the statistical model, but were found not to be significant. Given that the treatment levels of lysine were unequally spaced, the coefficients for the orthogonal polynomial contrasts were generated using SAS PROC IML. A repeated measures analysis, with treatment, time and time $\mathrm{x}$ treatment interaction as fixed effects, and horse nested within treatment as the random effect, was used to analyze plasma amino acid, urea, glucose and insulin concentration data. The autoregressive variance-covariance matrix was used to analyze the repeated measures data. In all cases, when fixed effects were significant, the means were separated using the Tukey-adjusted pdiff option. A broken

209 line analysis, as described by Robbins et al. (2005), using the NLIN procedure in SAS was 210 performed for lysine intake and phenylalanine oxidation. Starting estimates of breakpoint and line 211 slope were determined using a method previously described by Fadel (2004). This method of 212 broken line analysis has been applied to IAAO data for the determination of amino acid 213 requirements in pigs (Levesque et al., 2011).

\section{Results}

All horses remained healthy throughout the study, completed all study treatments and were included in all analyses per protocol. Horses were an average of $400 \pm 5$ days old and had a BW of 
$218358 \pm 5 \mathrm{~kg}$ on isotope infusion study days. Average daily gain for the yearlings while on treatment

219 diets was $0.25 \mathrm{~kg} / \mathrm{day}$.

Amino acid intakes

On the basis of muscle profiles, amino acid intakes exceeded NRC requirements (NRC, 2007), with the exceptions of histidine and threonine (Table 3). Lysine was also below NRC requirements (NRC, 2007) for three of the treatments, as dictated by the study design.

Plasma amino acid concentrations

Compared with baseline values ( $0 \mathrm{~min}$ ) (Table 4), plasma amino acid concentrations were greater at 90 min post-feeding $(P<0.001)$ (Table 5). Plasma lysine and glycine concentrations increased linearly $(P<0.05)$ within the 0 and 90 min time points with increasing lysine and glycine intakes, respectively (Tables 4 and 5).

\section{Plasma metabolite concentrations}

Plasma urea nitrogen, glucose, and insulin concentrations (Tables 4 and 5) were greater post-feeding (Table 5) than baseline values (Table 4; $P<0.01$ ), but were not affected by treatment $(P>0.05)$. The interactions between time and treatment were also not significant $(P>0.05)$, nor were linear, quadratic or cubic effects $(P>0.05)$.

\section{Muscle free amino acid concentrations}

Gluteus medius muscle free amino acid concentrations (Table 6) did not respond to 240 changing lysine intakes in the same manner as plasma amino acid concentrations (Tables 4 and 5).

241 Free asparagine, aspartate, arginine, glutamine, lysine, taurine and tryptophan concentrations 242 responded quadratically to lysine intake $(P<0.05)$. Free tyrosine concentrations responded 243 cubically to lysine intake $(P=0.04)$. 


\section{Phenylalanine kinetics}

Phenylalanine and tyrosine intakes were equivalent for all treatments. Phenylalanine flux,

247 release from protein breakdown, oxidation, non-oxidative disposal and balance did not differ

248 between treatments $(P>0.10$; Table 7). Linear, quadratic and cubic orthogonal contrasts on

249 phenylalanine kinetic parameters were also not significant $(P>0.05)$. A broken line analysis of 250 lysine intake and phenylalanine oxidation failed to yield a breakpoint from which to determine a 251 lysine requirement for yearling Thoroughbred colts (Fig. 1).

\section{Discussion}

This study underscores the limitations in our current knowledge regarding equine amino acid requirements and the need for further investigation into amino acids other than lysine that were potentially limiting in our treatment diets. We were unable to determine a breakpoint using the phenylalanine oxidation data (Fig. 1). Rates of non-oxidative phenylalanine disposal (Table 7) were not affected by treatment, but were less than those measured in weanlings (Tanner et al., 2014; Mastellar et al., 2016b) and only slightly greater than those measured in adult mares (Mastellar et al., 2016b). Phenylalanine balance was positive (Table 7), indicating that the yearlings were accreting protein. However, as this is the first time whole body protein synthesis was measured in yearling horses using this method, there is no data to compare these values with to determine if protein accretion was submaximal for this age of horse. Maximal whole body protein synthesis for yearlings would be expected to be only slightly higher than maximal for mature horses, since the average daily gain of yearlings is relatively small (Staniar et al., 2004).

The plasma metabolite concentrations also did not indicate a requirement (Tables 4 and 5). A previous study by Ohta et al. (2007) found a broken line in plasma lysine concentrations when 
min post-feeding plasma lysine concentrations with increasing lysine intake (Table 5). Additionally, there was no decrease in plasma threonine or methionine concentrations with increasing lysine intake, similar to that found by Malesky et al. (2013). Our plasma urea measurements also did not differ due to treatment as would be expected if an amino acid other than lysine was limiting in the basal diet. However, the timing of our blood sampling may not have been optimal to detect changes in plasma urea concentrations due to treatment, since another study found significant differences in plasma urea concentrations due to amino acid supplementation in horses sampled 3-4 h after meal feeding (Graham-Thiers and Kronfeld, 2005a).

Our data suggest that the lysine requirement of horses could be below the lowest level of lysine intake in the study (76 mg/kg BW/day). However, this is unlikely given the suggested requirements indicated in previous studies (Breuer and Golden, 1971; Fisher et al., 1989; NRC, 2007; Ohta et al., 2007). Another possibility would be that our IAAO data were unable to yield a lysine requirement for yearling horses receiving these diets (Table 1). An amino acid other than lysine that is equally limiting across our treatments diets could explain why a requirement could not be determined. This limitation would also explain our relatively poor growth rate over the course of the study.

Protein synthesis rates would not differ if all the diets were equally limiting in some amino acid other than lysine. Protein synthesis rates affect amino acid oxidation, plasma amino acid concentrations and plasma urea concentrations. Since there is limited data regarding amino acid requirements in horses, developing diets to contain adequate amounts of particular amino acids other than the test amino acid is inherently difficult. Candidates for universally limiting amino acids in the treatment diets include threonine and histidine (Table 3). The plasma urea data may be evidence of a universally limiting amino acid across treatments, since these values were relatively 
high when compared to other data reported in the literature (Graham-Thiers and Kronfeld, 2005a, b;

296 Winsco et al., 2011).

Using ratios for muscle tissue amino acids and the lysine requirement estimate provided by the NRC (2007), the threonine requirement estimate could be $70 \mathrm{mg} / \mathrm{kg} \mathrm{BW} /$ day for yearling horses (Bryden, 1991). Using ratios from other researchers that reported total equine muscle amino acids, the requirement would be $\sim 60 \mathrm{mg} / \mathrm{kg}$ BW/day (Badiani et al., 1997; Lorenzo and Pateiro, 2013). Using some of these estimates, our rations may have been deficient in threonine, which would explain the lack of response to lysine intake. Threonine digestibility has been shown to vary greatly in pigs according to feedstuff (Myrie et al., 2008).

If threonine was limiting, as the intake data suggests, it would be expected that threonine plasma concentrations would have been lower than is typical for equine plasma. The average across treatments in our study was $131 \mu \mathrm{mol} / \mathrm{L}$ threonine before feeding (Table 4). However, when compared to the values given in previous studies (Fisher et al., 1989; Hackl et al., 2006; Tanner et al., 2014) it does not appear to be low, which contradicts the idea that threonine could have been 311 limiting across all treatment diets. Given the lack of data in the literature specifically on yearling 312 plasma amino acid concentrations and differences in analysis methods, it is difficult to determine 313 whether the plasma threonine concentrations in our study were below the normal range. diets. Histidine as a potentially limiting amino acid in equine diets has previously been discussed by 317 Tanner et al. (2014). More research is needed to determine the adequacy and bioavailability of the amino acids provided in the treatment diets. Future research should endeavor to supply potential indispensable amino acids above estimated requirements. 
Although we were not able to determine a lysine requirement in this study, use of the IAAO

method for future research into amino acid requirements for horses should not be discouraged.

Phenylalanine kinetics were still able to distinguish between protein synthesis rates in weanling horses fed two different levels of protein (Tanner et al., 2014). This method has also been successfully used to determine lysine requirements in pigs (Bertolo et al., 2005) and human beings (Elango et al., 2007). Future studies in horses should take care to supplement diets with indispensable amino acids other than the test amino acid.

Our investigations found comparable gluteus medius free amino acid concentrations to those previously reported from freeze dried muscle (Miller-Graber et al., 1990). Muscle tissue free amino acids have been studied in the horse in response to exercise (Graham-Thiers et al., 2012), growth (Manso Filho et al., 2009) and feeding (Urschel et al., 2011). However, to our knowledge, this is the first time free tissue amino acids have been studied in response to supplementation of a single amino acid with isonitrogenous treatments in horses.

The underlying reasons for the differences in gluteus medius free amino acid concentrations between treatments are not entirely clear and more research is certainly warranted. Amino acid transporters are regulated by dietary lysine in the intestine (Wang et al., 2012) and other tissues (Humphrey et al., 2006). It is possible that lysine transporters could be upregulated at the lower lysine intakes, resulting in greater levels of lysine in the muscle at the lower levels of lysine intake. However, more research would need to be conducted to confirm this mechanism.

\section{Conclusions}

Supplementation of a single amino acid can affect the metabolism of amino acids at the tissue level, even if whole body protein synthesis is not affected. Our inability to determine a lysine requirement utilizing the IAAO method with these test diets underscores the paucity of data 
concerning amino acid requirement, adequacy and bioavailability data in the horse. Equine amino

348 acid requirements are an area in need of further research.

\section{Conflict of interest statement}

None of the authors of this paper have a financial or personal relationship with other people or organisations that could inappropriately influence or bias the content of the paper.

\section{Acknowledgements}

This is publication number 15-07-133 of the Kentucky Agricultural Experiment Station and is published with the approval of the Director. This work is supported by the National Institute of Food and Agriculture, United States Department of Agriculture (grant number 2010-65206-20638). Lyn Ennis contributed technical expertise with sample analysis. Preliminary results of this project were presented as abstracts at the Joint Annual Meeting of the American Society of Animal Science and American Dairy Science Association, Phoenix, AZ, USA, 15-19 July 2012, and the undergraduate interns Elizabeth Deluca and Lindsay Berg for their help with horse care, sampling and laboratory analysis.

\section{References}

AOAC, 2005. AOAC Official Method 994.12. Amino Acids in Feeds. In: Official Methods of Analysis of AOAC International, 18th Edn, Revision 1. Association of Official Agricultural Chemists (AOAC) International, Gaithersburg, Maryland, USA, pp. 9-19.

Badiani, A., Nanni, N., Gatta, P., Tolomelli, B., Manfredini, M., 1997. Nutrient profile of horsemeat. Journal of Food Composition and Analysis 10, 254.

Ball, R.O., Urschel, K.L., Pencharz, P.B., 2007. Nutritional consequences of interspecies differences in arginine and lysine metabolism. Journal of Nutrition 137, 1626S-1641S.

Bertolo, R.F., Moehn, S., Pencharz, P.B., Ball, R.O., 2005. Estimate of the variability of the lysine requirement of growing pigs using the indicator amino acid oxidation technique. Journal of Animal Science 83, 2535-2542. 
Bott, R.C., Greene, E.A., Trottier, N.L., Williams, C.A., Westendorf, M.L., Swinker, A.M., Mastellar, S.L., Martinson, K.L., 2015. Environmental implications of nitrogen output on horse operations: A review. Jourrnal of Equine Veterinary Science doi: 10.1016/j.jevs.2015.08.019.

Breuer, L.H., Golden, D.L., 1971. Lysine requirement of the immature equine. Journal of Animal Science 33, 227-227.

Brunton, J.A., Ball, R.O., Pencharz, P.B., 1998. Determination of amino acid requirements by indicator amino acid oxidation: Applications in health and disease. Current Opinion in Clinical Nutrition and Metabolic Care 1, 449-453.

Bryden, W.L., 1991. Amino acid requirements of horses estimated from tissue composition. Proceedings of the Nutrition Society of Australia 16, pp. 53-53.

Elango, R., Ball, R.O., Pencharz, P.B., 2008. Indicator amino acid oxidation: Concept and application. Journal of Nutrition 138, 243-246.

Elango, R., Humayun, M.A., Ball, R.O., Pencharz, P.B., 2007. Lysine requirement of healthy school-age children determined by the indicator amino acid oxidation method. American Journal of Clinical Nutrition 86, 360-365.

Elango, R., Humayun, M.A., Ball, R.O., Pencharz, P.B., 2009. Indicator amino acid oxidation is not affected by period of adaptation to a wide range of lysine intake in healthy young men. Journal of Nutrition 139, 1082-1087.

Fadel, J.G., 2004. Techinal note: Estimating parameters of nonlinear segmented models. Journal of Dairy Science 87, 169-173.

Fisher, M.G., Lawrence, L.M., Bump, K.D., Moser, L.R., Powell, D.M., 1989. Effects of dietary lysine level on plasma lysine, urea, and threonine in growing horses. Proceedings of the 11 th Equine Nutrition and Physiology Symposium 11, Stillwater, OK, USA, 18-29 May 1989, pp. 86-90.

Glade, M., Beller, D., Bergen, J., Berry, D., Blonder, E., Bradley, J., Cupelo, M., Dallas, J., 1985. Dietary protein in excess of requirements inhibits renal calcium and phosphorus reabsorption in young horses. Nutrition Reports International 31, 649-659.

Graham, P.M., Ott, E.A., Brendemuhl, J.H., TenBroeck, S.H., 1994. The effect of supplemental lysine and threonine on growth and development of yearling horses. Journal of Animal Science 72, 380-386.

Graham-Thiers, P.M., Kronfeld, D.S., 2005a. Amino acid supplementation improves muscle mass in aged and young horses. Journal of Animal Science 83, 2783-2788.

Graham-Thiers, P.M., Kronfeld, D.S., 2005b. Dietary protein influences acid-base balance in sedentary horses. Journal of Equine Veterinary Science 25, 434-438.

Graham-Thiers, P.M., Wilson, J.A., Haught, J., Goldberg, M., 2012. Relationships between dietary, plasma, and muscle amino acids in horses. Professional Animal Scientist 28, 351-357. 
Hackl, S., van den Hoven, R., Zickl, M., Spona, J., Zentek, J., 2006. Individual differences and repeatability of post-prandial changes of plasma-free amino acids in young horses. Journal of Veterinary Medicine. A, Physiology, Pathology, Clinical Medicine 53, 439-444.

Humphrey, B.D., Stephensen, C.B., Calvert, C.C., Klasing, K.C., 2006. Lysine deficiency and feed restriction independently alter cationic amino acid transporter expression in chickens (Gallus gallus domesticus). Comparative Biochemistry and Physiology A - Molecular and Integrative Physiology 143, 218-227.

Kurpad, A.V., Thomas, T., 2011. Methods to assess amino acid requirements in humans. Current Opinion in Clinical Nutrition and Metabolic Care 14, 434-439.

Levesque, C.L., Moehn, S., Pencharz, P.B., Ball, R.O., 2011. The threonine requirement of sows increases in late gestation. Journal of Animal Science 89, 93-102.

Lindholm, A., Piehl, K., 1974. Fibre composition, enzyme activity and concentrations of metabolites and electrolytes in muscles of standardbred horses. Acta Veterinaria Scandinavica 15, 287-309.

Lorenzo, J.M., Pateiro, M., 2013. Influence of type of muscles on nutritional value of foal meat. Meat Science 93, 630-638.

Malesky, S., Turner, J., Löest, C., Chen, L., Browne-Silva, J., 2013. Nitrogen retention and plasma amino acid responses in mature geldings fed three dietary concentrations of lysine. Journal of Equine Veterinary Science 33, 733-738.

Manso Filho, H.C., McKeever, K.H., Gordon, M.E., Manso, H.E., Lagakos, W.S., Wu, G., Watford, M., 2009. Developmental changes in the concentrations of glutamine and other amino acids in plasma and skeletal muscle of the Standardbred foal. Journal of Animal Science $87,2528-2535$.

Martin-Rosset, W., Tisserand, J.L., 2004. Evaluation and expression of protein allowances and protein value of feeds in the MADC system for the performance horse, In: Juliand, V. Martin-Rosset, W. (Eds). Nutrition of the Performance Horse: Which System in Europe for Evaluating the Nutritional Requirements? Wageningen Academic Publishers, Wageningen, The Netherlands, pp. 103-140.

Mastellar, S., Barnes, T., Cybulak, K., Urschel, K., 2016a. Splanchnic extraction of phenylalanine in mature mares was not affected by threonine supplementation. The Veterinary Journal 207, 190-192.

Mastellar, S., Moffet, A., Harris, P., Urschel, K., 2016b. Effects of threonine supplementation on whole-body protein synthesis and plasma metabolites in growing and mature horses. The Veterinary Journal 207, 147-153.

Matthews, D.E., Pesola, G., Campbell, R.G., 1990. Effect of epinephrine on amino acid and energy metabolism in humans. American Journal of Physiology 258, E948-956.

Metges, C.C., Petzke, K.J., Backes, G., Elsner, A., Junghans, P., Derno, M., Nurnberg, G., Hennig, U., 2005. Response to lysine in a wheat gluten diet in adult minipigs after short-and longterm dietary adaptation as assessed with an indicator amino acid oxidation and balance technique. Journal of Animal Science 83, 833-841. 
Miller-Graber, P.A., Lawrence, L.M., Kurcz, E., Kane, R., Bump, K., Fisher, M., Smith, J., 1990. The free amino-acid profile in the middle gluteal before and after fatiguing exercise in the horse. Equine Veterinary Journal 22, 209-210.

Moehn, S., Bertolo, R.F., Pencharz, P.B., Ball, R.O., 2004. Indicator amino acid oxidation responds rapidly to changes in lysine or protein intake in growing and adult pigs. Journal of Nutrition 134, 836-841.

Myrie, S.B., Bertolo, R.F., Sauer, W.C., Ball, R.O., 2008. Effect of common antinutritive factors and fibrous feedstuffs in pig diets on amino acid digestibilities with special emphasis on threonine. Journal of Animal Science 86, 609-619.

NRC, 2007. Nutrient Requirements of Horses, 6th Rev. Edn. National Research Council (NRC), National Academies Press, Washington DC, USA, 360 pp.

NRC, 2012. Nutrient Requirements of Swine, 11th Rev. Edn. National Research Council (NRC), Washington, DC, USA, $420 \mathrm{pp}$.

Ohta, Y., Yoshida, T., Ishibashi, T., 2007. Estimation of dietary lysine requirement using plasma amino acid concentrations in mature Thoroughbreds. Animal Science Journal 78, 41-46.

Ott, E.A., Asquith, R.L., Feaster, J.P., 1981. Lysine supplementation of diets for yearling horses. Journal of Animal Science 53, 1496-1503.

Panetta, D.M., Powers, W.J., Xin, H., Kerr, B.J., Stalder, K.J., 2006. Nitrogen excretion and ammonia emissions from pigs fed modified diets. Journal of Environmental Quality 35, 1297-1308.

Potter, G.D., Huchton, J.D., 1975. Growth of yearling horses fed different sources of protein with supplemental lysine, In: Proceedings of the 4th Equine Nutrition and Physiology Symposium. Equine Nutrition and Physiology Society, Pomona CA, pp. 19-20.

Reimers, T.J., Cowan, R.G., McCann, J.P., Ross, M.W., 1982. Validation of a rapid solid-phase radioimmunoassay for canine, bovine, and equine insulin. American Journal of Veterinary Research 43, 1274-1278.

Robbins, K., Saxton, A., Southern, L., 2005. Estimation of nutrient requirements using broken-line regression analysis. Journal of Animal Science 83, 60-60.

Staniar, W.B., Kronfeld, D.S., Hoffman, R.M., Wilson, J.A., Harris, P.A., 2004. Weight prediction from linear measures of growing Thoroughbreds. Equine Veterinary Journal 36, 149-154.

Tanner, S.L., Wagner, A.L., Digianantonio, R.N., Harris, P.A., Sylvester, J.T., Urschel, K.L., 2014. Dietary crude protein intake influences rates of whole-body protein synthesis in weanling horses. The Veterinary Journal 202, 236-243.

Tome, D., Bos, C., 2007. Lysine requirement through the human life cycle. Journal of Nutrition $137,1642 \mathrm{~S}-1645 \mathrm{~S}$. 
Tuitoek, K., Young, L.G., de Lange, C.F., Kerr, B.J., 1997. The effect of reducing excess dietary amino acids on growing-finishing pig performance: An elevation of the ideal protein concept. Journal of Animal Science 75, 1575-1583.

Tujioka, K., Lyou, S., Fukaya, Y., Sano, A., Hayase, K., Yokogoshi, H., 2005. Effect of adding dietary L-lysine, L-threonine and L-methionine to a low gluten diet on urea synthesis in rats. Amino Acids 28, 297-303.

Urschel, K.L., Escobar, J., McCutcheon, L.J., Geor, R.J., 2011. Effect of feeding a high-protein diet following an 18-hour period of feed withholding on mammalian target of rapamycindependent signaling in skeletal muscle of mature horses. American Journal of Veterinary Research 72, 248-255.

Urschel, K.L., Evans, A.R., Wilkinson, C.W., Pencharz, P.B., Ball, R.O., 2007. Parenterally fed neonatal piglets have a low rate of endogenous arginine synthesis from circulating proline. Journal of Nutrition 137, 601-606.

Urschel, K.L., Geor, R.J., Hanigan, M.D., Harris, P.A., 2012. Amino acid supplementation does not alter whole-body phenylalanine kinetics in arabian geldings. Journal of Nutrition 142, 461469.

Wang, X.Q., Zeng, P.L., Feng, Y., Zhang, C.M., Yang, J.P., Shu, G., Jiang, Q.Y., 2012. Effects of dietary lysine levels on apparent nutrient digestibility and cationic amino acid transporter mRNA abundance in the small intestine of finishing pigs, Sus scrofa. Animal Science Journal 83, 148-155.

Waterlow, J.C., Garlick, P.J., Millward, D.J., 1978. Protein Turnover in Mammalian Tissues and in the Whole Body. North-Holland, Amsterdam, The Netherlands, 804 pp.

Whittaker, A.G., Love, S., Parkin, T.D., Duz, M., Hughes, K.J., 2009. Stabling causes a significant increase in the pH of the equine airway. Equine Veterinary Journal 41, 940-943.

Winsco, K.N., Coverdale, J.A., Wickersham, T.A., Shelton, J.L., 2011. Influence of dietary methionine concentration on growth and nitrogen balance in weanling Quarter horses. Journal of Animal Science 89, 2132-2138.

Woodward, A.D., Nielsen, B.D., Liesman, J., Lavin, T., Trottier, N.L., 2011. Protein quality and utilization of timothy, oat-supplemented timothy, and alfalfa at differing harvest maturities in exercised Arabian horses. Journal of Animal Science 89, 4081-4092. 


\section{Table 1}

As-fed nutrient composition of feeds (mean \pm standard error) used in creating treatments with six levels of lysine intake for a controlled trial of yearling horses.

\begin{tabular}{|c|c|c|c|}
\hline & Timothy hay cubes ${ }^{\text {a }}$ & Low lysine concentrate ${ }^{b}$ & High lysine concentrate $^{c}$ \\
\hline \multicolumn{4}{|l|}{ Overall nutrient composition } \\
\hline Dry matter $(\%)$ & $91.2 \pm 0.2$ & $89.3 \pm 0.1$ & $89.6 \pm 0.5$ \\
\hline $\mathrm{DE}(\mathrm{Mcal} / \mathrm{kg})^{\mathrm{c}}$ & $1.69 \pm 0.11$ & $2.97 \pm 0.02$ & $3.06 \pm 0.06$ \\
\hline Crude protein $(\%)$ & $7.1 \pm 0.1$ & $13.9 \pm 0.1$ & $13.7 \pm 0.3$ \\
\hline Lignin $(\%)$ & $4.9 \pm 0.1$ & $0.8 \pm 0.3$ & $0.9 \pm 0.1$ \\
\hline $\mathrm{ADF}(\%)$ & $39.4 \pm 0.6$ & $10.1 \pm 0.5$ & $9.3 \pm 1.1$ \\
\hline $\mathrm{NDF}(\%)$ & $60.4 \pm 0.5$ & $19.9 \pm 0.7$ & $17.5 \pm 2.0$ \\
\hline Water soluble carbohydrates (\%) & $10.9 \pm 0.3$ & $3.9 \pm 0.1$ & $4.1 \pm 0.1$ \\
\hline Ethanol soluble carbohydrates $(\%)$ & $5.6 \pm 0.2$ & $2.3 \pm 0.8$ & $2.8 \pm 0.3$ \\
\hline $\operatorname{Starch}(\%)$ & $1.0 \pm 0.1$ & $32.3 \pm 0.4$ & $33.4 \pm 1.9$ \\
\hline Crude fat $(\%)$ & $1.6 \pm 0.1$ & $6.7 \pm 0.1$ & $7.1 \pm 0.1$ \\
\hline Calcium $(\%)$ & $0.37 \pm 0.01$ & $1.86 \pm 0.10$ & $1.94 \pm 0.17$ \\
\hline Phosphorus (\%) & $0.20 \pm 0.01$ & $0.30 \pm 0.01$ & $0.32 \pm 0.02$ \\
\hline Iron $(\mathrm{mg} / \mathrm{kg})$ & $149 \pm 6$ & $175 \pm 9$ & $215 \pm 61$ \\
\hline Zinc $(\mathrm{mg} / \mathrm{kg})$ & $101 \pm 16$ & $114 \pm 6$ & $126 \pm 34$ \\
\hline \multicolumn{4}{|c|}{ Amino acid composition ( $\mathrm{g} / 100 \mathrm{~g}$ feed $)$} \\
\hline Alanine $(\%)$ & $0.34 \pm 0.03$ & $0.62 \pm 0.02$ & $0.61 \pm 0.01$ \\
\hline Arginine (\%) & $0.35 \pm 0.04$ & $0.61 \pm 0.03$ & $0.60 \pm 0.01$ \\
\hline Aspartate + Asparagine $(\%)$ & $0.51 \pm 0.04$ & $0.61 \pm 0.06$ & $0.53 \pm 0.05$ \\
\hline Glutamate + Glutamine (\%) & $0.64 \pm 0.07$ & $2.50 \pm 0.09$ & $2.57 \pm 0.08$ \\
\hline Glycine $(\%)$ & $0.25 \pm 0.02$ & $1.06 \pm 0.02$ & $0.40 \pm 0.01$ \\
\hline Histidine (\%) & $0.05 \pm 0.01$ & $0.16 \pm 0.01$ & $0.16 \pm 0.01$ \\
\hline Isoleucine $(\%)$ & $0.28 \pm 0.03$ & $0.51 \pm 0.02$ & $0.47 \pm 0.02$ \\
\hline Leucine $(\%)$ & $0.47 \pm 0.04$ & $1.19 \pm 0.02$ & $1.19 \pm 0.02$ \\
\hline Lysine $(\%)$ & $0.25 \pm 0.02$ & $0.37 \pm 0.02$ & $0.92 \pm 0.05$ \\
\hline Methionine (\%) & $0.02 \pm 0.01$ & $0.59 \pm 0.06$ & $0.70 \pm 0.05$ \\
\hline Phenylalanine (\%) & $0.32 \pm 0.02$ & $0.60 \pm 0.01$ & $0.60 \pm 0.02$ \\
\hline Proline $(\%)$ & $0.36 \pm 0.03$ & $0.98 \pm 0.03$ & $0.98 \pm 0.01$ \\
\hline Serine $(\%)$ & $0.19 \pm 0.01$ & $0.32 \pm 0.04$ & $0.45 \pm 0.03$ \\
\hline Threonine (\%) & $0.18 \pm 0.01$ & $0.38 \pm 0.01$ & $0.38 \pm 0.01$ \\
\hline Tyrosine (\%) & $0.14 \pm 0.02$ & $0.39 \pm 0.03$ & $0.39 \pm 0.02$ \\
\hline Valine $(\%)$ & $0.35 \pm 0.02$ & $0.56 \pm 0.02$ & $0.53 \pm 0.01$ \\
\hline
\end{tabular}

${ }^{\mathrm{b}}$ Mixed for this experiment by Buckeye Nutrition; for ingredient composition see Table 2 .

$579{ }^{\mathrm{c}}$ Diets were top-dressed with $0.43 \mathrm{~mL} / \mathrm{kg}$ body weight/day canola oil to increase the DE of the diets. 
Table 2

581 Composition of high and low lysine concentrates for a controlled trial of yearling horses. ${ }^{\text {a }}$

\begin{tabular}{lcc}
\hline \multirow{2}{*}{ Ingredient } & \multicolumn{2}{c}{ Amount $(\%)$} \\
\cline { 2 - 3 } Wheat & Low lysine concentrate & High lysine concentrate \\
Soy hulls & 46.558 & 46.551 \\
Oatmill byproduct & 16.251 & 16.264 \\
Corn gluten & 14.109 & 14.105 \\
Calcium carbonate & 7.221 & 7.22 \\
Soybean oil & 4.95 & 4.949 \\
Cane molasses & 4.967 & 4.966 \\
Corn distiller's dry grain & 2.458 & 2.456 \\
DL-Methionine & 1.264 & 1.262 \\
Glycine & 0.833 & 0.833 \\
Lysine & 0.669 & - \\
Rolled oats & - & 0.846 \\
Threonine & 0.171 & - \\
Gro 'N Win ${ }^{b}$ & 0.168 & 0.168 \\
Selenium premix & 0.13 & 0.13 \\
Zinc sulfate & 0.093 & 0.093 \\
Magnesium oxide & 0.029 & 0.03 \\
Monocalcium phosphate $(21 \%)$ & 0.027 & 0.027 \\
Dyna K ${ }^{\mathrm{c}}$ & 0.028 & 0.028 \\
Dynamate ${ }^{\mathrm{d}}$ & 0.028 & 0.028 \\
Copper II Sulfate & 0.028 & 0.028 \\
\hline
\end{tabular}

$584 \quad{ }^{\mathrm{a}}$ Information provided by Buckeye Nutrition.

$585{ }^{\mathrm{b}}$ Gro 'N Win is a ration balancer pellet produced by Buckeye Nutrition.

$586{ }^{\mathrm{c}}$ Dyna $\mathrm{K}$ is a potassium chloride product made by The Mosaic Company.

$587{ }^{\mathrm{d}}$ Dynamate is a potassium and magnesium sulfate product made by The Mosaic Company. 
588

589

590

591

Table 3

Amino acid intakes ( $\mathrm{mg} / \mathrm{kg}$ body weight/day) for different dietary treatments and requirements based on the tissue composition of equine muscle for a controlled trial of yearling horses.

\begin{tabular}{|c|c|c|c|c|c|c|c|c|}
\hline \multirow[b]{2}{*}{ Lysine } & \multicolumn{6}{|c|}{ Dietary treatments } & \multirow{2}{*}{$\frac{\text { Standard deviation }}{7}$} & \multirow{2}{*}{$\frac{\text { Requirement estimates }^{a}}{113}$} \\
\hline & 76 & 90 & 104 & 118 & 127 & 136 & & \\
\hline Alanine & 116 & 116 & 116 & 115 & 115 & 115 & 5 & - \\
\hline Arginine & 116 & 115 & 115 & 115 & 114 & 114 & 8 & 84 \\
\hline Aspartate + Asparagine & 138 & 136 & 134 & 132 & 131 & 130 & 12 & - \\
\hline Glutamate + Glutamine & 365 & 367 & 368 & 370 & 371 & 373 & 19 & - \\
\hline Glycine & 152 & 135 & 118 & 101 & 89 & 78 & 4 & - \\
\hline Histidine & 25 & 25 & 25 & 25 & 25 & 25 & 3 & 73 \\
\hline Isoleucine & 95 & 94 & 93 & 92 & 92 & 91 & 6 & 63 \\
\hline Leucine & 195 & 196 & 196 & 196 & 196 & 196 & 8 & 123 \\
\hline Methionine & 69 & 72 & 74 & 77 & 79 & 81 & 7 & 33 \\
\hline Phenylalanine & 110 & 110 & 110 & 110 & 110 & 110 & 4 & 68 \\
\hline Proline & 158 & 158 & 158 & 158 & 159 & 159 & 6 & - \\
\hline Serine & 61 & 65 & 68 & 71 & 74 & 76 & 5 & - \\
\hline Threonine & 66 & 66 & 66 & 66 & 66 & 66 & 3 & 70 \\
\hline Tyrosine & 62 & 62 & 62 & 63 & 63 & 63 & 6 & - \\
\hline Valine & 110 & 109 & 109 & 108 & 108 & 107 & 5 & 71 \\
\hline
\end{tabular}

$593 \quad{ }^{a}$ Estimates based on gluteal muscle profiles as proposed by Bryden (1991). 
Table 4

595 Plasma metabolites before $(t=0$ min $)$ feeding of the morning concentrate portion of diets providing varying lysine 596 levels for a controlled trial of yearling horses.

\begin{tabular}{|c|c|c|c|c|c|c|c|c|c|c|}
\hline & \multicolumn{6}{|c|}{$\begin{array}{l}\text { Dietary lysine content } \\
\text { (mg/kg body weight/day) }\end{array}$} & \multirow[t]{2}{*}{ Pooled SE ${ }^{\mathrm{a}}$} & \multicolumn{3}{|c|}{$P$ values ${ }^{\mathrm{b}}$} \\
\hline & 76 & 90 & 104 & 118 & 127 & 136 & & Treatment & Time & Treatment $\mathrm{x}$ Time \\
\hline Urea (mmol/L) & 4.4 & 4.6 & 4.3 & 4.1 & 3.5 & 4.8 & 1.5 & 0.72 & $<0.001$ & 0.98 \\
\hline Glucose (mmol/L) & 4.93 & 4.72 & 5.15 & 4.2 & 5.27 & 4.94 & 0.43 & 0.68 & $<0.001$ & 0.44 \\
\hline Insulin $(\mu \mathrm{IU} / \mathrm{mL})$ & 1.89 & 2.18 & 1.52 & 1.73 & 2.25 & 2.52 & 1.24 & 0.82 & $<0.001$ & 0.84 \\
\hline \multicolumn{11}{|c|}{ Amino acids $(\mu \mathrm{mol} / \mathrm{L})$} \\
\hline Alanine & 190 & 192 & 194 & 182 & 189 & 181 & 13 & 0.44 & $<0.001$ & 0.52 \\
\hline Arginine & 41 & 59 & 48 & 51 & 35 & 48 & 13 & 0.17 & $<0.001$ & 0.56 \\
\hline Asparagine & 19 & 19 & 20 & 17 & 18 & 19 & 4 & 0.67 & $<0.001$ & 0.77 \\
\hline Aspartate & 40 & 37 & 36 & 36 & 37 & 34 & 3 & 0.35 & $<0.001$ & 0.8 \\
\hline Citrulline & 104 & 106 & 107 & 105 & 100 & 107 & 11 & 0.84 & $<0.001$ & 0.62 \\
\hline Glutamate & 345 & 300 & 301 & 316 & 356 & 339 & 57 & 0.27 & $<0.001$ & 0.89 \\
\hline Glutamine & 223 & 275 & 264 & 230 & 227 & 219 & 42 & 0.42 & $<0.001$ & 0.18 \\
\hline Glycine $^{c}$ & 825 & 697 & 717 & 623 & 670 & 690 & 78 & $<0.001$ & $<0.001$ & 0.03 \\
\hline Histidine & 70 & 73 & 72 & 68 & 66 & 74 & 7 & 0.83 & $<0.001$ & 0.7 \\
\hline Isoleucine & 57 & 59 & 56 & 57 & 53 & 56 & 8 & 0.46 & $<0.001$ & 0.98 \\
\hline Leucine & 105 & 107 & 105 & 102 & 98 & 100 & 16 & 0.4 & $<0.001$ & 0.79 \\
\hline Lysine & 95 & 106 & 102 & 110 & 105 & 118 & 19 & $<0.001$ & $<0.001$ & $<0.001$ \\
\hline Methionine & 80 & 78 & 76 & 78 & 81 & 71 & 16 & 0.2 & $<0.001$ & 0.8 \\
\hline Ornithine & 101 & 89 & 92 & 87 & 95 & 91 & 21 & 0.34 & $<0.001$ & 0.87 \\
\hline Phenylalanine & 62 & 63 & 63 & 61 & 61 & 64 & 6 & 0.59 & $<0.001$ & 0.86 \\
\hline Proline & 121 & 117 & 116 & 110 & 113 & 113 & 16 & 0.97 & $<0.001$ & 0.88 \\
\hline Serine & 271 & 265 & 268 & 241 & 247 & 251 & 28 & 0.32 & $<0.001$ & 0.91 \\
\hline Taurine & 51 & 44 & 49 & 51 & 50 & 51 & 5 & 0.75 & $<0.001$ & 0.76 \\
\hline Threonine & 137 & 132 & 133 & 119 & 123 & 139 & 14 & 0.32 & $<0.001$ & 0.31 \\
\hline Tryptophan & 7 & 6 & 6 & 6 & 6 & 6 & 1 & 0.73 & 0.03 & 0.55 \\
\hline Tyrosine & 91 & 95 & 93 & 97 & 95 & 97 & 6 & 0.67 & $<0.001$ & 0.97 \\
\hline Valine & 152 & 146 & 140 & 141 & 131 & 140 & 18 & 0.25 & $<0.001$ & 0.97 \\
\hline
\end{tabular}

$600{ }^{\mathrm{b}}$ Treatment, time and treatment by time interaction $P$ values are shown in Tables 4 and 5 .

$601{ }^{\mathrm{c}}$ Quadratic within baseline time point $(P<0.05)$. 
Table 5

Plasma metabolites 90 min after feeding of the morning concentrate portion of diets providing varying lysine levels for a controlled trial of yearling horses.

\begin{tabular}{|c|c|c|c|c|c|c|c|c|c|c|}
\hline & \multicolumn{6}{|c|}{$\begin{array}{l}\text { Dietary lysine content } \\
\text { (mg/kg body weight/day) }\end{array}$} & \multirow[t]{2}{*}{ Pooled SE ${ }^{\mathrm{a}}$} & \multicolumn{3}{|c|}{$P$ values ${ }^{\mathrm{b}}$} \\
\hline & 76 & 90 & 104 & 118 & 127 & 136 & & Treatment & Time & Treatment $\mathrm{x}$ Time \\
\hline Urea (mmol/L) & 13.7 & 13.6 & 13 & 13.6 & 13 & 11.9 & 1.5 & 0.72 & $<0.001$ & 0.98 \\
\hline Glucose (mmol/L) & 6.38 & 6.35 & 6.28 & 6.43 & 6.47 & 6.59 & 0.43 & 0.68 & $<0.001$ & 0.44 \\
\hline Insulin $(\mu \mathrm{IU} / \mathrm{mL})$ & 6.86 & 7.06 & 6.04 & 8.16 & 6.9 & 6.91 & 1.24 & 0.82 & $<0.001$ & 0.84 \\
\hline \multicolumn{11}{|c|}{ Amino acids $(\mu \mathrm{mol} / \mathrm{L})$} \\
\hline Alanine & 271 & 304 & 283 & 294 & 291 & 292 & 13 & 0.44 & $<0.001$ & 0.52 \\
\hline Arginine & 68 & 92 & 82 & 95 & 72 & 88 & 13 & 0.17 & $<0.001$ & 0.56 \\
\hline Asparagine & 39 & 34 & 35 & 37 & 33 & 35 & 4 & 0.67 & $<0.001$ & 0.77 \\
\hline Aspartate & 60 & 54 & 53 & 58 & 55 & 55 & 3 & 0.35 & $<0.001$ & 0.80 \\
\hline Citrulline & 141 & 135 & 137 & 132 & 129 & 131 & 11 & 0.84 & $<0.001$ & 0.62 \\
\hline Glutamate & 403 & 363 & 377 & 357 & 404 & 439 & 57 & 0.27 & $<0.001$ & 0.89 \\
\hline Glutamine & 445 & 451 & 454 & 497 & 445 & 418 & 42 & 0.42 & $<0.001$ & 0.18 \\
\hline Glycine $^{c}$ & 998 & 887 & 854 & 737 & 709 & 703 & 78 & $<0.001$ & $<0.001$ & 0.03 \\
\hline Histidine & 97 & 101 & 99 & 97 & 103 & 100 & 7 & 0.83 & $<0.001$ & 0.70 \\
\hline Isoleucine & 80 & 82 & 78 & 85 & 77 & 81 & 8 & 0.46 & $<0.001$ & 0.98 \\
\hline Leucine & 170 & 164 & 163 & 180 & 160 & 174 & 16 & 0.40 & $<0.001$ & 0.79 \\
\hline Lysine & 148 & 181 & 199 & 286 & 288 & 323 & 19 & $<0.001$ & $<0.001$ & $<0.001$ \\
\hline Methionine & 215 & 215 & 189 & 232 & 210 & 203 & 16 & 0.20 & $<0.001$ & 0.80 \\
\hline Ornithine & 134 & 108 & 115 & 119 & 127 & 120 & 21 & 0.34 & $<0.001$ & 0.87 \\
\hline Phenylalanine & 85 & 86 & 84 & 90 & 86 & 89 & 6 & 0.59 & $<0.001$ & 0.86 \\
\hline Proline & 217 & 212 & 215 & 221 & 223 & 223 & 16 & 0.97 & $<0.001$ & 0.88 \\
\hline Serine & 350 & 323 & 337 & 314 & 319 & 315 & 28 & 0.32 & $<0.001$ & 0.91 \\
\hline Taurine & 64 & 63 & 59 & 60 & 62 & 61 & 5 & 0.75 & $<0.001$ & 0.76 \\
\hline Threonine & 221 & 192 & 193 & 203 & 205 & 196 & 14 & 0.32 & $<0.001$ & 0.31 \\
\hline Tryptophan & 7 & 7 & 7 & 7 & 6 & 7 & 1 & 0.73 & 0.03 & 0.55 \\
\hline Tyrosine & 127 & 126 & 125 & 133 & 130 & 128 & 6 & 0.67 & $<0.001$ & 0.97 \\
\hline Valine & 199 & 190 & 182 & 195 & 177 & 191 & 18 & 0.25 & $<0.001$ & 0.97 \\
\hline
\end{tabular}

$607{ }^{a}$ SE, standard error.

$608{ }^{\mathrm{b}}$ Treatment, time and treatment by time interaction $P$ values are shown in Tables 4 and 5 .

$609 \quad{ }^{\mathrm{c}}$ Linear within 90 min time point $(P<0.05)$. 
Table 6

611 Free amino acids $(\mu \mathrm{mol} / \mathrm{g}$ ) in freeze dried gluteus medius muscle from yearling horses fed varying levels of lysine $\sim 100$ 612 min after a morning concentrate meal.

\begin{tabular}{|c|c|c|c|c|c|c|c|c|c|c|c|}
\hline & \multicolumn{6}{|c|}{$\begin{array}{l}\text { Dietary lysine content } \\
\text { (mg/kg body weight/day) }\end{array}$} & \multirow{2}{*}{$\begin{array}{l}\text { Pooled } \\
\text { standard } \\
\text { error }\end{array}$} & \multicolumn{4}{|c|}{$P$ values } \\
\hline & 76 & 90 & 104 & 118 & 127 & 136 & & Treatment & Linear & Quadratic & Cubic \\
\hline 3-Methyl histidine & 0.86 & 0.66 & 0.81 & 1.03 & 0.99 & 1.04 & 0.16 & 0.29 & 0.08 & 0.44 & 0.20 \\
\hline Alanine & 3.06 & 2.04 & 2.85 & 2.72 & 3.13 & 3.73 & 0.63 & 0.50 & 0.26 & 0.16 & 0.71 \\
\hline Asparagine & 0.49 & 0.31 & 0.35 & 0.40 & 0.37 & 0.57 & 0.10 & 0.37 & 0.54 & 0.05 & 0.93 \\
\hline Aspartate & 0.83 & 0.57 & 0.53 & 0.66 & 0.64 & 0.90 & 0.13 & 0.31 & 0.66 & 0.03 & 0.84 \\
\hline Arginine & 0.26 & 0.25 & 0.25 & 0.25 & 0.25 & 0.27 & 0.27 & 0.06 & 0.82 & 0.01 & 0.53 \\
\hline Carnosine & 86.42 & 71.64 & 85.90 & 94.23 & 93.47 & 91.31 & 13.68 & 0.72 & 0.34 & 0.76 & 0.27 \\
\hline Citrulline & 0.40 & 0.27 & 0.38 & 0.36 & 0.36 & 0.40 & 0.07 & 0.63 & 0.71 & 0.36 & 0.45 \\
\hline Cysteine & 8.06 & 6.25 & 6.31 & 7.05 & 7.27 & 7.00 & 1.86 & 0.96 & 0.90 & 0.50 & 0.54 \\
\hline Glutamate & 4.75 & 3.09 & 4.19 & 4.10 & 4.46 & 4.57 & 0.83 & 0.67 & 0.69 & 0.30 & 0.34 \\
\hline Glutamine & 5.61 & 3.42 & 4.42 & 4.32 & 4.54 & 6.60 & 1.14 & 0.33 & 0.46 & 0.04 & 0.96 \\
\hline Glycine & 4.42 & 3.81 & 3.54 & 3.30 & 4.43 & 3.37 & 0.79 & 0.74 & 0.54 & 0.55 & 0.53 \\
\hline Histidine & 0.40 & 0.23 & 0.33 & 0.27 & 0.31 & 0.31 & 0.08 & 0.54 & 0.60 & 0.29 & 0.39 \\
\hline Isoleucine & 0.23 & 0.17 & 0.19 & 0.24 & 0.23 & 0.22 & 0.04 & 0.30 & 0.49 & 0.32 & 0.06 \\
\hline Leucine & 0.52 & 0.38 & 0.44 & 0.50 & 0.51 & 0.51 & 0.08 & 0.51 & 0.47 & 0.33 & 0.17 \\
\hline Lysine & 0.50 & 0.37 & 0.20 & 0.38 & 0.54 & 0.78 & 0.13 & 0.12 & 0.11 & 0.01 & 0.78 \\
\hline Methionine & 0.54 & 0.45 & 0.46 & 0.56 & 0.51 & 0.55 & 0.07 & 0.80 & 0.63 & 0.44 & 0.42 \\
\hline Ornithine & 1.02 & 0.39 & 1.01 & 0.77 & 0.64 & 0.79 & 0.39 & 0.48 & 0.79 & 0.67 & 0.42 \\
\hline Phenylalanine & 0.10 & 0.09 & 0.11 & 0.09 & 0.10 & 0.09 & 0.02 & 0.98 & 0.79 & 0.97 & 0.73 \\
\hline Proline & 0.52 & 0.35 & 0.44 & 0.44 & 0.45 & 0.53 & 0.09 & 0.74 & 0.75 & 0.24 & 0.60 \\
\hline Serine & 1.39 & 0.86 & 1.04 & 1.13 & 1.10 & 1.29 & 0.18 & 0.33 & 0.93 & 0.07 & 0.29 \\
\hline Taurine & 3.24 & 3.14 & 3.43 & 4.45 & 3.94 & 9.21 & 1.38 & 0.01 & 0.01 & 0.01 & 0.11 \\
\hline Threonine & 1.25 & 0.86 & 0.86 & 1.05 & 1.54 & 1.44 & 0.45 & 0.61 & 0.38 & 0.19 & 0.53 \\
\hline Tryptophan & 0.19 & 0.12 & 0.12 & 0.13 & 0.13 & 0.19 & 0.03 & 0.24 & 0.98 & 0.02 & 1.00 \\
\hline Tyrosine & 0.41 & 0.29 & 0.39 & 0.42 & 0.45 & 0.39 & 0.06 & 0.21 & 0.34 & 0.65 & 0.04 \\
\hline Valine & 0.51 & 0.38 & 0.42 & 0.48 & 0.46 & 0.46 & 0.07 & 0.61 & 0.94 & 0.35 & 0.18 \\
\hline
\end{tabular}


Table 7

615 Whole body phenylalanine kinetics in yearling Thoroughbred colts that were receiving graded levels of dietary lysine. ${ }^{\text {a }}$

616

\begin{tabular}{|c|c|c|c|c|c|c|c|c|c|c|c|}
\hline & \multicolumn{6}{|c|}{ Graded lysine intakes (mg/kg body weight/day) } & \multirow{2}{*}{$\begin{array}{c}\text { Pooled } \\
\text { SE }\end{array}$} & \multicolumn{4}{|c|}{$P$ values } \\
\hline & 76 & 90 & 104 & 118 & 127 & 136 & & Treatment & Linear & Quadratic & Cubic \\
\hline Phenylalanine flux (mmol/kg body weight/h) & 49 & 49 & 52 & 52 & 46 & 49 & 3 & 0.53 & 0.76 & 0.26 & 0.97 \\
\hline Carbon dioxide production ( $\mathrm{mmol} / \mathrm{kg}$ body weight $/ \mathrm{h})$ & 19411 & 18762 & 20794 & 20192 & 19883 & 17974 & 1085 & 0.22 & 0.71 & 0.06 & 0.13 \\
\hline \multicolumn{12}{|c|}{ Phenylalanine entering the free phenylalanine pool $(\mathrm{mmol} / \mathrm{kg} \text { body weight } / \mathrm{h})^{\mathrm{b}}$} \\
\hline Phenylalanine from dietary intake ${ }^{c}$ & 13.5 & 13.9 & 13.8 & 13.6 & 13.4 & 13.5 & 0.2 & 0.22 & 0.27 & 0.11 & 0.06 \\
\hline Phenylalanine from protein breakdown & 35.6 & 35.1 & 38.1 & 38.6 & 32.7 & 35.4 & 2.9 & 0.57 & 0.81 & 0.32 & 0.93 \\
\hline \multicolumn{12}{|c|}{ Phenylalanine leaving the free phenylalanine pool (mmol/kg body weight $/ \mathrm{h})^{\mathrm{b}}$} \\
\hline Phenylalanine oxidation & 6.1 & 5.7 & 7.1 & 6.5 & 5.3 & 7.1 & 1.2 & 0.77 & 0.73 & 0.96 & 0.68 \\
\hline Non-oxidative phenylalanine disposal & 42.7 & 43.1 & 44.5 & 45.4 & 40.8 & 41.6 & 2.8 & 0.81 & 0.70 & 0.31 & 0.87 \\
\hline Phenylalanine balance $(\mathrm{mmol} / \mathrm{kg} \text { body weight } / \mathrm{h})^{d}$ & 7.4 & 8.2 & 6.7 & 7.0 & 8.2 & 6.4 & 1.3 & 0.79 & 0.66 & 0.85 & 0.89 \\
\hline
\end{tabular}

\section{7}

$618{ }^{a}$ Values are least squares means \pm standard error (SE) determined using one-way analysis of variance.

$619{ }^{\mathrm{b}}$ Stochastic model of phenylalanine kinetics used: flux = rate of phenylalanine entry = rate of phenylalanine leaving; rate of phenylalanine entry =

620 phenylalanine intake + phenylalanine release from protein breakdown; rate of phenylalanine leaving = phenylalanine oxidation + non-oxidative

621 phenylalanine disposal; a splanchnic phenylalanine extraction rate of $50 \%$ was assumed when calculating the amount of dietary phenylalanine

622 reaching general circulation.

$623{ }^{\mathrm{c}}$ Values were adjusted for estimated prececal digestibilities of 40 and $70 \%$ for forage and concentrate, respectively, and a splanchnic extraction of

$624 \quad 26.5 \%$.

$625{ }^{\mathrm{d}}$ Phenylalanine balance $=$ non-oxidative phenylalanine disposal - phenylalanine release from protein breakdown. 


\section{Figure legend}

627

628 Fig. 1. Plotting lysine intake and phenylalanine oxidation fail to yield a breakpoint to indicate the

629 lysine requirement for yearling Thoroughbred colts. Six colts were fed diets containing graded

630 amounts of lysine. Phenylalanine oxidation was not affected by diet $(P>0.10)$. 


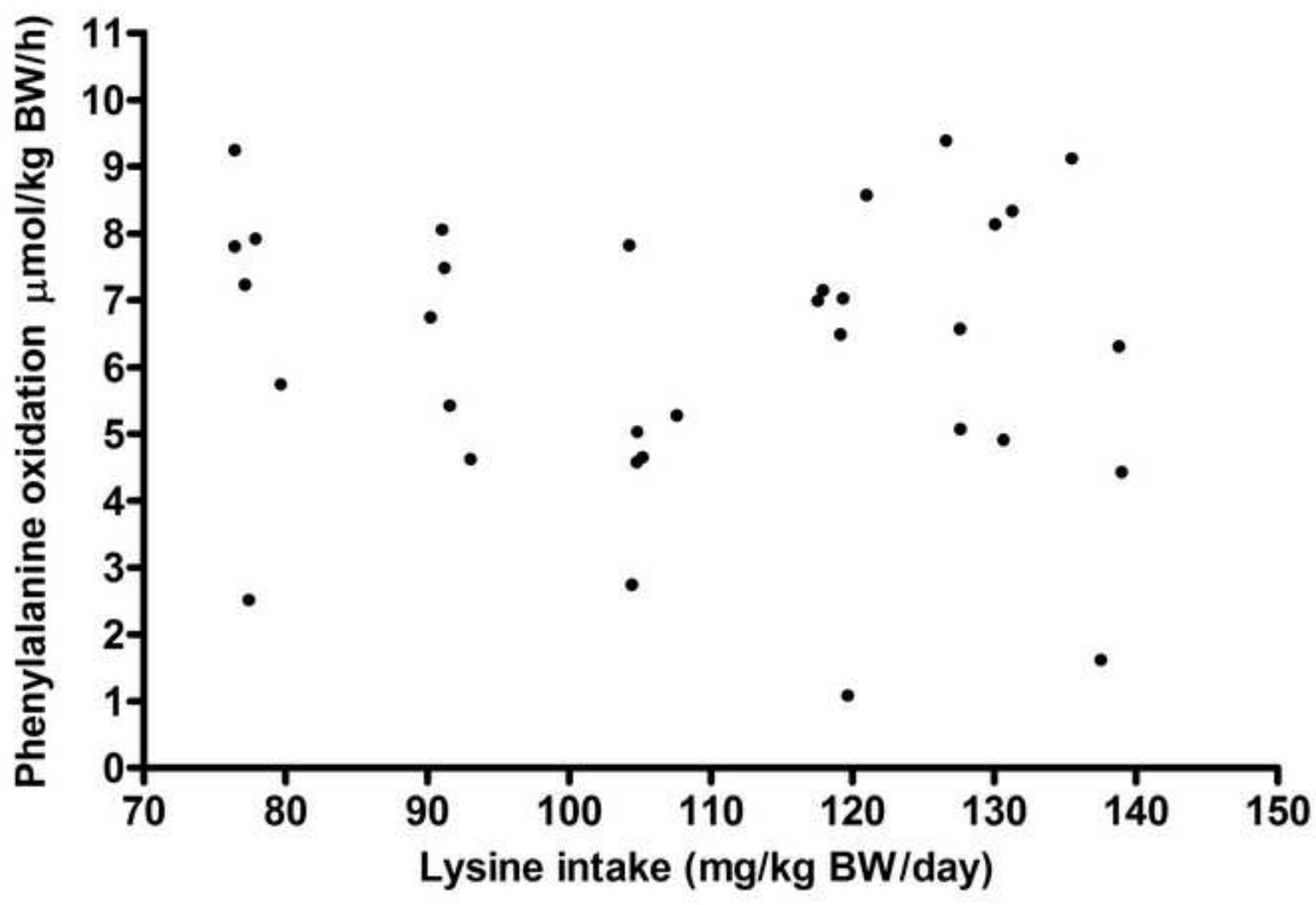

